\title{
PENINGKATAN MOTIVASI BELAJAR SISWA SECARA ONLINE PADA PELAJARAN ANIMASI 2D MELALUI STRATEGI KOMUNIKASI PERSUASIF
}

\author{
Arifah Suryaningsih \\ SMK Negeri 2 Sewon \\ fafaguru@gmail.com
}

\begin{abstract}
Abstrak: Laporan best practice ini bertujuan untuk merekam seluruh kegiatan pembelajaran secara jarak jauh (online) yang dilakukan selama masa Pandemi Covid-19. Penelitian ini juga dilakukan untuk mengetahui keberhasilan pembelajaran yang dilaksanakan oleh peneliti dengan menggunakan strategi komunikasi persuasif yang digunakan untuk mengetahui hubungan antara motivasi belajar dengan semangat berkreasi siswa dalam pembuatan animasi 2D. Jumlah sampel yang digunakan adalah 64 orang siswa-siswi Kelas XI Jurusan Multimedia SMK Negeri 2 Sewon Bantul. Hasil penelitian ini menunjukkan bahwa motivasi belajar siswa sempat menurun pada minggu ke-5 pada pelaksanaan BDR. Strategi yang telah dilakukan penulis, yaitu dengan menjalin komunikasi persuasif dengan siswa baik secara group maupun pribadi, mampu meningkatkan motivasi belajar dan meningkatkan kreatifitas dalam membuat karya pada siswa. Terdapat peningkatan respon dalam grup WhatsApp dan penyerahan tugas-tugas secara langsung maupun tugas yang di unggah melalui laman media sosial masing-masing siswa.
\end{abstract}

Kata kunci: motivasi belajar, komunikasi persuasif

\section{IMPROVEMENT OF STUDENTS' MOTIVATION IN ONLINE LEARNING OF $2 D$ ANIMATION THROUGH THE PERSUASIVE COMMUNICATION STRATEGY}

\begin{abstract}
This best practice reports online learning activities during the Covid-19 pandemic period. This study was conducted to determine the influence of persuasive communication strategy to the relationship between learning motivation and students' creative enthusiasm in making $2 D$ animations. Subject of the study was 64 students in class of XI Multimedia at SMK Negeri 2 Sewon, Bantul. The results of this study indicate that student motivation decreased at the 5th week of school from home (SFH) program. The application of persuasive communication strategy for students that was carried out in this study both in groups and privately increase their motivation and creativity during the completion of their assigments. There was also an increase of response in the WhatsApp group for direct submission of student assignments as well as accomplishment of assignments that had to be uploaded in the student's personal social media.
\end{abstract}

Keywords: learning motivation, persuasive communication.

\section{PENDAHULUAN}

Corona Virus Diseases 2019 (Covid-19) sudah menjadi pandemi dunia, hal ini memaksa hampir semua sektor merubah pola aktivitasnya. Termasuk sektor pendidikan. Selama pandemi ini belum berakhir dan situasi dinyatakan aman, pembelajaran dalam jaringan (daring)/online akan terus diberlakukan. Itu artinya mau tidak mau, suka tidak suka guru, siswa dan juga orang tua harus berkecimpung dalam dunia cyber selama waktu yang tidak bisa ditentukan. Situasi pembelajaran dengan model daring ini memberi kesempatan untuk mentransformasi pendidikan kita. Semua guru harus bisa mengajar jarak jauh dengan memanfaatkan teknologi.

Sementara itu pembelajaran secara online tetap harus bisa menjaga motivasi belajar dan mendorong siswa untuk tetap kreatif mengakses sebanyak mungkin sumber pengetahuan, menghasilkan karya, mengasah wawasan dan ujungnya membentuk siswa menjadi pembelajar sepanjang hayat. Dimotori oleh guru sebagai fasilitator, pembelajaran online bukan sekedar memberikan tugas atau memindahkan materi melalui jaringan internet, kemudian selesai. Namun lebih dari itu. Engagement (kedekatan/keterlibatan) antara guru dan siswa harus terus dirawat. Apapun platform digital yang digunakan, memanusiakan hubungan adalah hal yang tetap harus diutamakan. Diskusi dan komunikasi harus terus dihidupkan diantara guru dan siswa. Sapaan ringan, candaan segar, guyonan hingga melakukan dialog serius sebisa mungkin tetap dilakukan.

Mode online digunakan untuk memastikan kontinuitas belajar-mengajar dan proses 
penilaian. Mode online atau mode e-learning tidak hanya melakukan sesi konferensi video atau berbagi Slide PowerPoint, video dan dokumen untuk pelajar. Pembelajaran dengan cara Online dapat efektif hanya jika mempromosikan pembelajaran aktif di pada peserta didik dengan memberikan kesempatan untuk membaca, menulis, berdiskusi, pikirkan, ajukan pertanyaan, selesaikan masalah, analisis, dan menciptakan yang baru, semua hal tergantung pada konten pembelajaran. Dalam konteks ini, itu saatnya bagi kita untuk memikirkan 'pembelajaran fleksibel', yang berpusat pada peserta didik. Pendekatan yang berpusat pada peserta didik ini menawarkan pilihan belajar yang lebih kaya kepada siswa. Dalam sebuah mode online pembelajaran akan lebih fleksibel, siswa disediakan berbagai pilihan untuk pembelajaran mereka dan memungkinkan mereka untuk mengambil lebih banyak tanggung jawab untuk pembelajaran mereka sendiri. Zayapragassarazan (2020).

Karena pada keadaan yang serba berubah pada masa pandemi Covid-19 ini, kecenderungan menurunnya motivasi belajar siswa semakin terasa. Hal ini terjadi karena beberapa faktor, seperti yang diungkapkan pada hasil survei Save the Children di Indonesia dalam bentuk penilaian cepat atau rapid needs assessment terkait Covid-19, yang dilakukan secara daring tanggal 10-27 April 2020. Responden sebanyak 11.989 orang tua/publik, 4.698 guru negeri dan swasta, diikuti survei lanjutan terhadap 883 responden lainnya. Selain itu ada wawancara mendalam terhadap 417 responden (kepala desa, kader kesehatan, guru, dan orang tua yang tinggal di kota dan desa).

Disebutkan Helen (2020), bahwa puluhan juta anak di Tanah Air berpotensi menghadapi tujuh risiko akibat pandemi Covid-19. Adapun ketujuh risiko yang dialami dan akan dihadapi anak-anak selama pandemi adalah, pertama berkurangnya kesejahteraan anak akibat pendapat orang tua hilang (30 persen) atau menurun(72 persen); kedua anak kesulitan mengakses layanan kesehatan dasar; ketiga anak kesulitan mengakses layanan pendidikan berkualitas; keempat terbatasnya dukungan bagi anak dengan disabilitas (833.000 anak disabilitas sulit mengakses informasi dan panduan kesehatan tentang Covid-19); kelima banyak anak kehilangan orang tua (60 persen kasus Covid-19 menimpa usia produktif dan memiliki anak); dan keenam, rentan terhadap kekerasan. "Sebanyak 46 persen responden orang tua mengatakan anaknya mengalami masalah berikut: sulit berkonsentrasi, bingung, susah tidur, stress, mudah lelah, dan kesepian". Risiko ketujuh adalah bertambahnya kesengsaraan bagi korban bencana alam. "Generasi ini (anak-anak) mengalami situasi yang luar biasa di saat mereka berada pada usia anak. Tetapi belum semua orang tua menyadari sepenuhnya apa yang mereka alami saat ini maupun dalam jangka panjang ke depan.

Vivin, dkk (2019), mengungkapkan dalam penelitiannya bahwa bahwa semakin tinggi kecemasan, maka semakin rendah motivasi belajar dan sebaliknya semakin rendah kecemasan maka semakin tinggi motivasi belajar. Hasil penelitian ini menunjukkan bahwa ada hubungan negatif antara kecemasan dengan motivasi belajar. Siswa-siswi yang tidak memiliki perasaan cemas berlebihan, akan mampu mengatasi situasi pembelajaran yang sulit dengan mempersiapkan diri melalui kegiatan belajar. Sebaliknya siswa-siswi yang mengalami perasaan cemas berlebihan akan cenderung memiliki persepsi negatif sehingga tidak memiliki motivasi dan gairah belajar.

Di masa pandemi Covid-19 ini pada hakekatnya belajar bukan sekedar mentransfer pengetahuan, ada sisi humanistik yang harus terus dirawat. Dalam kondisi yang serba sulit bagi siswa karena perubahan ini juga karena keterbatasan medium, guru harus kreatif menciptakan suasana diskusi. Jika hubungan interaktif tercipta maka akan ada saluransaluran positif yang dapat gigunakan untuk melewatkan ilmu pengetahuan.

Sementara Pada jenjang Sekolah Menengah Kejuruan (SMK). Tantangan pembelajaran secara daring pastinya menjadi lebih berat. Pendidikan di SMK lebih bertujuan untuk mencetak Sumber Daya Manusia yang terampil dan siap bekerja. Dengan pola pembelajaran teori $40 \%$ dan praktik $60 \%$ tidak mudah menjalankan pembelajaran pada masa andemi seperti ini.

Hal berat yang paling terasa adalah, pada beberapa jurusan, khususnya jurusan Multimedia yang diampu oleh penulis. Lebih dari $80 \%$ siswa yang berasal dari masyarakat ekonomi menengah kebawah tidak memiliki fasilitas praktik penunjang belajar yang memadai. Kendala ini menjadi tantangan guru mata pelajaran peminatan (kejuruan) untuk mengatur strategi, bagaimana caranya siswa 
tetap bisa berkarya pada bidangnya dengan meminimalisir peralatan yang mereka punya.

Sehingga best practise ini mencoba mengungkap hasil setelah dilakukan upaya meningkatkan motivasi siswa untuk tetap kreatif dalam berkarya, khususnya karya animasi 2D dengan cara membangun komunikasi yang lebih baik kepada siswa, baik secara bersamaan (group) maupun secara personal (jalur pribadi/japri) secara online.

\section{KAJIAN LITERATUR Motivasi Belajar}

Motivasi belajar diartikan sebagai keseluruhan daya penggerak baik dalam diri maupun dari luar siswa (dengan tidak menciptakan serangkaian usaha untuk menyediakan kondisi kondisi tertentu) yang menjamin kelangsungan dan memberikan arah pada kegiatan belajar, sehingga tujuan yang dikehendaki oleh subyek belajar itu dapat tercapai. Motivasi ekstrinsik bersumber atau kemunculan dari luar diri setiap orang. Motivasi intrinsik mempunyai arti seperti bunyinya, yaitu memotivasi dari dalam diri seseorang, seseorang melakukan sesuatu karena ingin melakukannya. Motivasi ekstrinsik berasal dari luar diri orang tertentu. Leavitt (1992),

Sardiman dalam Zain (2017) menyebutkan bahwa interaksi kegiatan belajarmengajar berdasarkan motivasi siswa menunjukkan minat, inisiatif dan aktif dalam kegiatan belajar. Sehingga akan terbentuk komunikasi timbal-balik antara guru dan siswa. Dengan demikian, akan diperoleh hasil yang lebih baik bagi siswa yaitu tidak sekedar ilmu pengetahuan tapi juga nilai-nilai yang bisa membentuk perkembangan pribadi siswa seutuhnya.

\section{Strategi Komunikasi Persuasif}

Ada beragam definisi komunikasi persuasif yang dikemukakan oleh para ahli. Menurut Kamus Ilmu Komunikasi (dalam Rakhmad, 2008: 14), komunikasi persuasif diartikan sebagai suatu proses untuk mempengaruhi pendapat, sikap dan tindakan orang dengan menggunakan manipulasi psikologis sehingga orang tersebut bertindak seperti atas kehendaknya sendiri. Selain itu, dari orang yang diajak berkomunikasi secara persuasif. komunikasi persuasif juga diartikan sebagai komunikasi yang dilakukan sebagai ajakan atau bujukan agar mau bertindak sesuai dengan keinginan komunikator (Barata, 2003:70).

Menurut Devito, usaha melakukan persuasi ini memusatkan perhatian pada upaya mengubah atau memperkuat sikap atau kepercayaan halayak atau pada upaya mengajak mereka bertindak dengan cara tertentu. Persuasi juga dipahami sebagai usaha merubah sikap melalui penggunaan pesan dan berfokus pada karakteristik komunikator dan pendengar (Devito, 2011: 499).

Dalam Zain (2017), komunikasi persuasif menggunakan teori yang dicetuskan oleh Wilbur Schramm 1950-an the bullet theory of communication atau teori peluru. Ia disebut pula dengan hypodermic-needle theory atau teori jarum hipodermik. Kadang-kadang disebut pula transmission belt theory atau teori lajur transmisi. Dalam teori ini dibahas mengenai pengaruh pesan yang disalurkan melalui media massa dan mengatakan bahwa media massa itu ampuh untuk mengubah perilaku massa. Komunikasi persuasif memiliki sasaran yang berkorelasi dengan motivasi dari orang yang diajak berkomunikasi secara persuasif. Motivasi (motivation) diartikan sebagai kekuatan dorongan, kebutuhan semangat, tekanan atau mekanisme psikologis yang mendorong seseorang atau sekelompok orang untuk mencapai apa yang dikehendakinya (Danim, 2004: 2).

Dalam melakukan pendekatan komunikasi personal menurut Djamarah $(2005,165)$ dalam Zain (2017) guru harus melakukan beberapa hal diantaranya adalah:

a. Mendengarkan secara simpati dan menanggapi secara positif pikiran anak didik dan membuat hubungan saling percaya

b. Membantu anak didik dengan pendekatan verbal dan pendekatan non verbal

c. Membantu anak didik tanpa harus mendominasi atau mengambil alih tugas

d. Menerima perasaan anak didik sebagaimana adanya atau menerima perbedaannya dengan penuh perhatian

e. Menangani anak didik dengan rasa aman, penuh pengertian, dan mungkin memberikan beberapa alternatif pemecahan

\section{HASIL DAN PEMBAHASAN}

Tempat pelaksanaan best practice ini dilaksanakan di rumah guru dan masingmasing siswa yang sedang melaksanakan pembelajran jarak-jauh dengan terkoneksi 
internet. Pembelajaran ini dilaksanakan pada semester genap tahun ajaran 2019/2020. Mulai minggu pertama diterapkannya kebijakan Belajar dan Bekerja Dari Rumah sampai minggu ke delapan. Dimulai pada 16 Maret 2020 sd 13 Mei 2020. (8 Minggu efektif).

Sedangkan pelaksanaan pembelajaran dilakukan sesuai dengan jadwal pelajaran Teknik Animasi 2 Dimensi kelas XI Multimedia-1 sejumlah 32 siswa, dan kelas XI Multimedia 2 sejumlah 32 Siswa. Total siswa adalah 64 orang.

Pada saat pandemi ini terjadi, pembelajaran dipaksa harus dilakukan secara online. Hal ini mengagetkan banyak pihak, khususnya bagi para guru dan juga siswa sebagai pelaku utama dalam sebuah kelas pembelajaran.

\section{Keadaan Awal}

Permasalahan yang timbul dari sisi siwa adalah semakin hari guru merasakan adanya penurunan motivasi belajar siswa. Hal ini terbukti dengan kurangnya respon siswa dalam menanggapi komunikasi yang dijalin oleh guru melalui grup Whatsapp. Sehingga guru cenderung sepihak dalam memberikan materi maupun penugasan. Hal ini tentu saja menyulitkan guru dalam rangka memahamkan materi maupun tugas yang harus dijelaskan secara rinci dan dibangun atas dasar komunikasi secara lancar.

Berikut ini data penurunan tanggapan/respon siswa pada komunikasi yang dijalin guru pada grup Whatsapp:

\section{Grafik respon tanggapan siswa pada diskusi kelas Whatsapp}

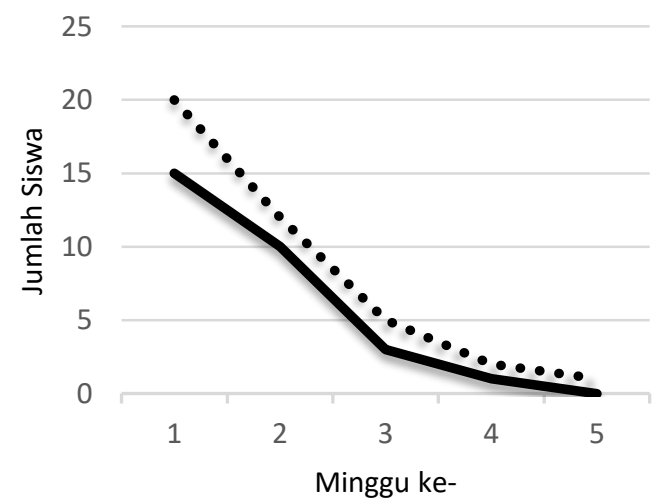

Kelas XI Multimedia 1

•.. Kelas XI Multimedia 2

Gambar 1. Grafik respon siswa

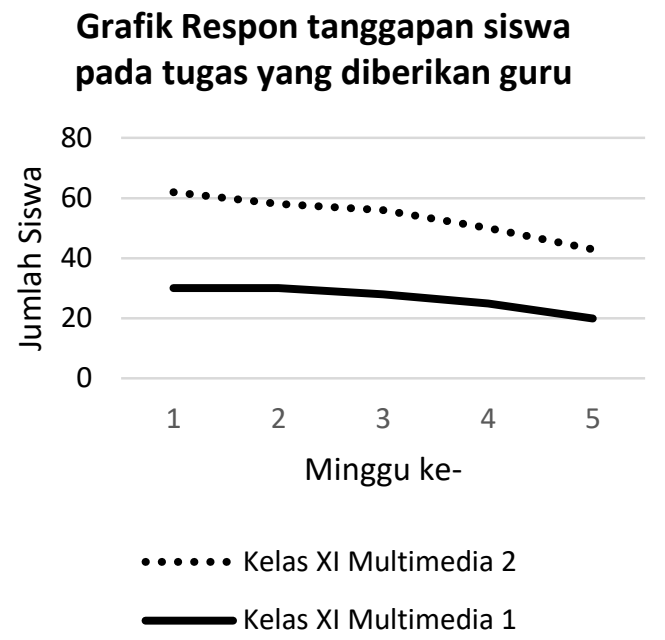

Gambar 2. Grafik respon siswa pada tugas

\section{Pelaksanaan Praktik Baik}

Menyadari kondisi tersebut, dilakukan pendekatan komunikasi persuasif kepada beberapa siswa yang benar-benar tidak ada respon dalam diskusi materi, pengerjaan tugas, maupun quis yang guru lakukan di grup Whatsapp. Berikut ini adalah tahapan operasional yang dilakukan:

1. Review KD

2. Pemberian Motivasi

3. Pemberian Materi, Penugasan dan Quiz

4. Rekap respon Siswa

5. Penerapan Strategi Komunikasi Persuasif

6. Rekap respon Siswa setelah pelaksanaan strategi

7. Merilis hasil belajar ke siswa

\section{Strategi}

Penulis melakukan diskusi sebelumnya dengan siswa untuk memilih jenis animasi apa yang akan dan mampu mereka kerjakan dengan fasilitas yang mereka punyai di rumah masingmasing. Akhirnya disepakati siswa akan membuat project Animasi stop motion. Animasi ini adalah salah satu bentuk animasi yang bisa dikerjakan cukup dengan dengan menggunakan smartphone dengan dukungan ide serta kreativitas tinggi yang harus dipancing terlebih dahulu. Berikut ini tahapan yang dilakukan untuk meningkatkan motivasi dan kreatifitas siswa dalam membuat karya Animasi 2D

1. Penjelasan Materi, Diskusi dan Pemberian Uraian Tugas Project

Hal pertama yang penulis lakukan adalah memberi contoh konkret produk animasi stop motion yang akan menjadi penugasan project mereka. Saya membuat animasi ini dalam 
waktu setengah hari, kemudian menugaskan kepada mereka dalam waktu 1 minggu. Sehingga cukup untuk mereka mulai dari menggali ide, menyiapkan properti, melakukan pengambilan gambar, mengedit hingga mengunggahnya di media social. Berikut ini link yang bisa diakses untuk melihat karya contoh yang guru bagikan kepada siswa: https://www.youtube.com/watch?v=5tlf_bJFrt4 2. Rekapitulasi respon siswa

Setelah instruksi disampaikan ke seluruh siswa tercatat ada beberapa siswa yang memberikan tanggapan sebagai berikut:

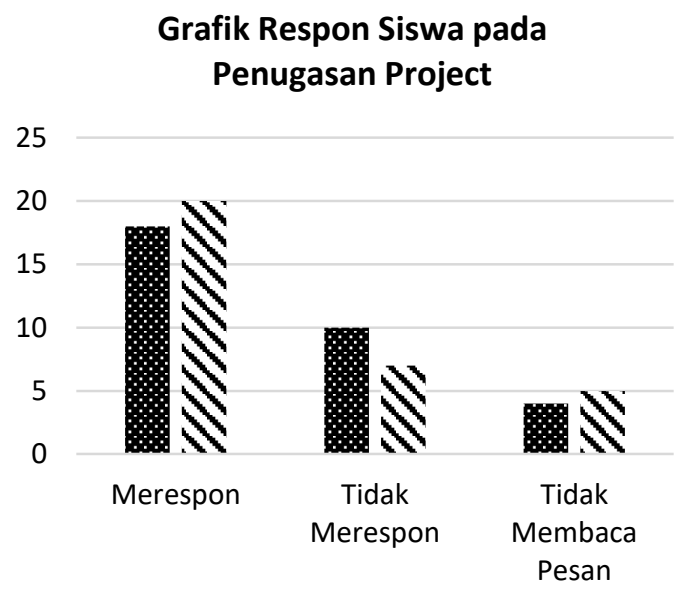

\$ Kelas XI MM 1 、Kelas Xi MM 2

Gambar 3. Grafik Respon Siswa Pada Project

\section{Grafik Pengumpulan Tugas Project}

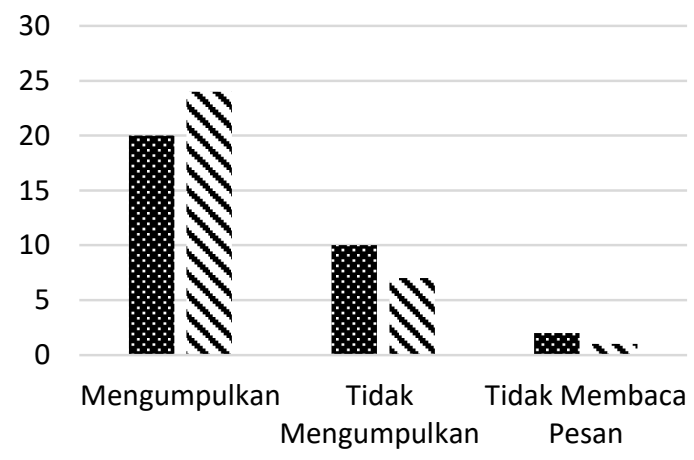

I Kelas XI MM 1 Velas XI MM 2

Gambar 4. Grafik Pengumpulan Tugas Project

3. Penerapan Strategi Komunikasi Persuasif

Berikut ini bentuk strategi komunikasi yang guru berikan kepada siwa untuk meningkatkan motivasi belajar dan menyelesaikan karya animasi 2D
Tabel 1. Daftar model komunikasi yang diterapkan oleh guru di kelas

\begin{tabular}{|c|c|c|}
\hline $\mathrm{No}$ & Jenis Sapaan & Isi Komunikasi \\
\hline 1 & Sapaan & $\begin{array}{l}\checkmark \text { Selamat pagi } \\
\checkmark \text { Semoga semua dalam keadaan } \\
\quad \text { sehat } \\
\checkmark \text { Semangat! } \\
\checkmark \text { Tetap di rumah aja } \\
\checkmark \text { Terus berkarya ya } \\
\checkmark \text { Salam sehat buat semua }\end{array}$ \\
\hline 2 & $\begin{array}{l}\text { Penyampaian } \\
\text { Motivasi }\end{array}$ & $\begin{array}{l}\checkmark \text { Jangan lupa terus berkarya } \\
\checkmark \text { Jangan biarkan waktumu } \\
\text { terbuang sia-sia } \\
\checkmark \text { Pandemi ini memang berat, tapi } \\
\text { yakinlah semua kan berlalu } \\
\checkmark \text { Allah tidak akan memberi } \\
\text { cobaan melebihi kekuatan } \\
\text { hambanya } \\
\checkmark \text { Tidak ada yang bisa merubah } \\
\text { nasib kecuali diri kalian sendiri } \\
\checkmark \text { Silakan yang mungkin belum } \\
\text { sempat post karya di instagram, } \\
\text { kita sudah tidak sabar } \\
\text { menunggu }\end{array}$ \\
\hline 3 & Hin & $\begin{array}{l}\checkmark \text { Sebaiknya atur lagi waktumu } \\
\text { dengan baik } \\
\checkmark \text { Coba dijadwalkan dan dipatuhi } \\
\checkmark \text { Kalian yang bisa mengatur dan } \\
\text { mengontrol diri sendiri, jadi } \\
\text { tolong bisa disiplin dan } \\
\text { komitmen pada diri sendiri } \\
\checkmark \text { Jangan melakukan hal-hal yang } \\
\text { konyol dan membuang waktu } \\
\checkmark \text { Ayo yang lain, ditunggu } \\
\text { postingan karyanya! }\end{array}$ \\
\hline 4 & Teg & $\begin{array}{l}\checkmark \text { Tolong diperhatikan apa yang } \\
\text { ada di diskusi kelas kita } \\
\checkmark \text { Sebaiknya kalian coba pahami } \\
\text { dengan baik instruksi dari bu } \\
\text { Guru } \\
\checkmark \text { Jika kamu menyepelekan kelas, } \\
\text { bu Guru tidak bisa menjamin } \\
\text { kompetensimu bisa meningkat } \\
\checkmark \text { Pelajaran Animasi 2D ini } \\
\text { adalah pelajaran peminatan } \\
\text { produktif yang seharusnya } \\
\text { kalian kuasai dan punya } \\
\text { portofolio project } \\
\checkmark \text { Silakan segera mengirimkan } \\
\text { karyanya, paling lambat:... }\end{array}$ \\
\hline 5 & Pujian & $\begin{array}{l}\checkmark \text { Terimakasih } \\
\checkmark \text { Keren } \\
\checkmark \text { Hebat } \\
\checkmark \text { Lanjutkan guys } \\
\checkmark \text { Pertamax, silakan yang lain } \\
\quad \text { menyusul } \\
\checkmark \text { Catet! } \\
\checkmark \text { Kerja yang bagus, lanjutkan! } \\
\checkmark \text { Dll.. }\end{array}$ \\
\hline
\end{tabular}


Setelah beberapa kali dilakukan komunikasi secara persuasif, baik melalui Whatsapp Group maupun jalur pribadi, Selanjutnya diperoleh lebih banyak siswa yang menanggapi project mereka dengan antusias. Melalui Whatsapp Group kami berkoordinasi, berdiskusi dan juga saling menyemangati. Guru memeriksa progress pekerjaan mereka pada hari ke-3 setelah detail penugasan di bagikan. Juga memberikan pengulangan materi animasi Stop Motion sehingga mampu menguatkan kembali pemahaman mereka tentang animasi tersebut. Guru juga memberikan kesempatan kepada siswa yang merasa sungkan untuk bertanya di WA group untuk berkomunikasi secara pribadi (japri) kepada guru. Sehingga kendala yang dihadapi bisa diminimalisir dengan bantuan dari guru.

Selanjutnya sesuasi dengan tenggat waktu yang diberikan, Guru melakukan pengecekan melalui tagar \#stopmotioncoronaskarose pada instagram, dan hasil karya siswa bisa diakses pada link berikut ini: https://www. instagram.com/explore/tags/stopmotioncorona skarose/. Diperoleh 29 karya animasi yang sudah diunggah di instagram oleh siswa (per tanggal 25 April 2020). Sedangkan jumlah siswa yang diampu sebanyak 64 siswa. Artinya sampai dengan batas waktu yang ditentukan, ada $45 \%$ siswa yang sudah melaksanakan tugas membuat karya secara tepat waktu dan tepat media. Sedangkan siswa yang sudah mengirimkan melalui whatsapp sebanyak 16 siswa (25\%). Total siswa yang telah mengumpulkan tugas karya Animasi Stop Motion adalah sebanyak $29+16=45$ Siswa (70\%). Artinya tingkat keberterimaan dan antusias siswa terhadap pembuatan karya produk animasi di masa pandemi tetap bagus.

Sedangkan total siswa yang belum mengumpulkan, akan dilakukan treatment pendekatan strategi komunikasi persuasif oleh guru dengan cara yang sudah diuraikan diatas. Khususnya beberapa siswa yang masih belum bisa memenuhi penugasan tersebut, guru akan melakukan komunikasi persuasif secara Whatsapp jalur pribadi (WA Japri). Sehingga dipastikan mereka akan tetap menyelesaikan tugasnya namun tidak tepat waktu. Masih ditunggu sampai dengan satu minggu kedepannya, dengan upaya guru melakukan pendekatan dan melakukan bantuan yang bisa memudahkann siswa menyelesaikan tugasnya. Sehingga hasil total yang diharapkan pada projek ini akan mencapai minimal 90\%.
Berikut ini link terbaik dua karya siswa dan tangkapan layar beberapa hasil karya animasi stop motion siswa SMK 2 Sewon Jurusan Multimedia kelas XI. https://www. instagram.com/p/B_WvZ2MDL0a/?igshid $=12$ wfekelst10r dan https://www.instagram.com/ p/B_Wf-tdFPv5/?igshid=1pgcp $854 \times$ nny 47

Hasil dari pengerjaan tugas/proyek animasi siswa yang bisa terlihat langsung bisa dinikmati melalui akun instagram melalui layar $\mathrm{hp}$, membuat siswa semakin termotivasi untuk berkarya lebih baik lagi. Karena hasil karyanya bukan hanya sekedar untuk menuntaskan pembelajaran pada mata pelajaran Animasi 2D namun juga memberi manfaat bagi masyarakat luas yaitu menambah referensi informasi seputar pandemi Covid-19 yang disajikan dalam bentuk animasi yang lebih menarik.

\section{SIMPULAN DAN SARAN}

Berdasarkan observasi dan dokumentasi yang telah dikumpulkan dan dianalisis, dapat disimpulkan secara umum bahwa penerapan pembelajaran jarak jauh pada masa pandemi akan menyurutkan motivasi belajar siswa. Hal tersebut harus segera diketahui oleh guru untuk mencari strategi yang paling tepat dalam mengelola kelasnya. Strategi yang telah dilakukan penulis, yaitu dengan menjalin komunikasi persuasif dengan siswa baik secara group maupun pribadi, mampu meningkatkan motivasi belajar dan membuat karya pada siswa. Terdapat peningkatan respon dalam group WhatsApp dan penyerahan tugas-tugas secara langsung maupun di unggah melalui laman media sosial pribadi masing-masing.

Implikasinya dalam penerapan model pembelajaran dengan strategi komunikasi persuasif dalam proses belajar jarak jauh adalah terjadi adanya proses interaksi antara siswa dengan guru dan lingkungan belajar yang bertujuan menghasilkan suatu perubahan tingkah laku, perubahan yang awalnya malas merespon, menjadi merespon dengan positif. Dan melakukan skenario pembelajaran yang telah disepakati bersama di dalam kelas.

Dengan adanya hasil best practice tersebut di atas, penulis dapat merekomendasikan bahwa peningkatan motivasi belajar menggunakan strategi komunikasi persuasif dapat diusulkan untuk dipergunakan pada semua guru pada semua mata pelajaran dalam kondisi Pandemi Covid-19. Karena sebagai pendidik yang juga berperan sebagai motivator, seorang guru harus selalu menjaga semangat 
dan motivasi siswa mengikuti proses pembelajaran, terutama dalam konsdisi yang bagi siswa adalah hal yang tidak nyaman dan harus mengontrol dirinya sendiri ketika belajar dari rumah. Masih diperlukan pengembangan metode dan strategi lain untuk menjawab berbagai permasalahan yang timbul dalam situasi belajar dari rumah di masa pandemi ini. Sehingga kondisi terbaik yang guru ciptakan akan lebih meningkatkan minat dan motivasi belajar siswa. Dengan meningkatkan minat dan motivasi belajar siswa akan tercipta suasana belajar yang kondusif, kompetitif dan merangsang pemikiran kritis dan kreatif dari seluruh siswa.

\section{DAFTAR PUSTAKA}

Barata, A. A. (2003). Dasar-Dasar Pelayanan Prima. Jakarta: Elex Media.

Danim, S. (2004). Motivasi Kepemimpinan dan Efektifitas Kelompok. Jakarta: Rineka Cipta.

Djamarah, S. B. (2005). Guru dan Anak Didik Dalam Interaksi Edukatif: Suatu Pendekatan Teoritis Psikologis. Jakarta: Rineka Cipta.

Leavitt, H. J. (1992). Psikologi Manajemen. Jakarta: Erlangga.
Rakhmad, J. (2011). Psikologi Komunikasi. Bandung: Remaja Rosdakarya.

Sinombor, S. H. (2020). Anak Rentan Alami Berbagai Risiko Saat Pandemi Covid-19. Harian Nasional Kompas 22 Mei 2020. Diakses melalui kompas.id:

https://kompas.id/baca/humaniora/dikbud/202 0/05/22/anak-rentan-alami-berbagairisiko-saat-pandemi-covid-19/

Susanti, L. (2019). Strategi Pembelajaran Berbasis Motivasi. Jakarta: Elex media computindo

Vivin, M, dkk. (2017). Kecemasan dan motivasi belajar. Persona: Jurnal Psikologi Indonesia. Volume 8. No.2 Desember 2019

Zain, N. L. (2017). Strategi Komunikasi Persuasif dalam Meningkatkan Motivasi Belajar Siswa. Jurnal Nomosleca, Volume 3, Nomor 2, Oktober 2017

Zayapragassarazan, Z. COVID-19: Strategies for Engaging Remote Learners in Medical Education [version 1; not peer reviewed]. F1000Research 2020, 9:273 (document) diakses pada (https://doi.org/ 10.7490/f1000research.1117846.1) 